Document downloaded from:

http://hdl.handle.net/10251/95438

This paper must be cited as:

Oster, U.; Molés-Cases, T. (2016). Eating and drinking seen through translation: A study of food-related translation difficulties and techniques in a parallel corpus of literary texts. Across Languages and Cultures. 17(1):53-75. doi:10.1556/084.2016.17.1.3

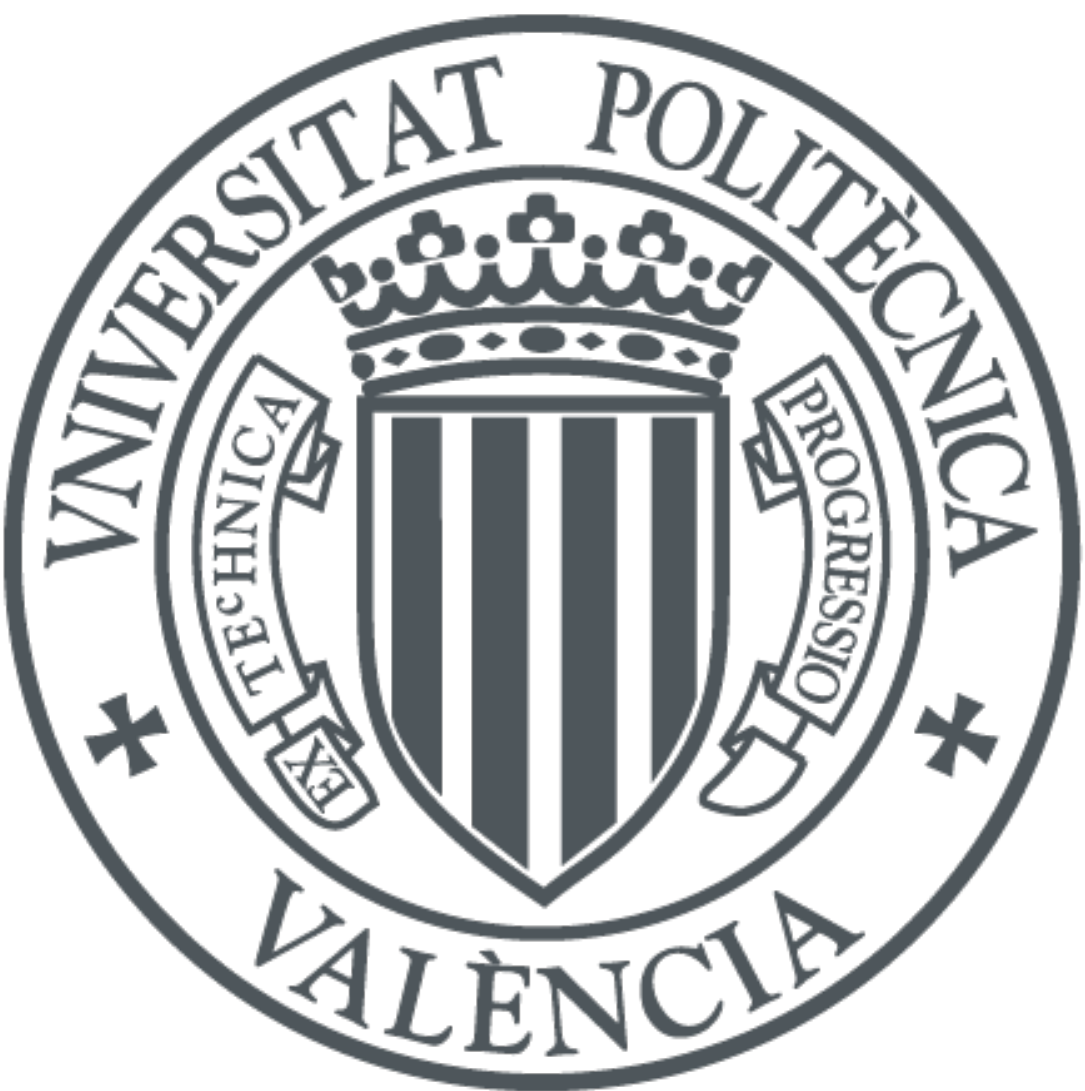

The final publication is available at

https://doi.org/10.1556/084.2016.17.1.3

Copyright Akademiai Kiado Zrt.

Additional Information 


\title{
Eating and drinking seen through translation: A study of food-related translation difficulties and techniques in a parallel corpus of literary texts
}

Keywords: Food and culture in translation, parallel corpora, translation techniques, literary translation

Ulrike Oster \& Teresa Molés-Cases

\begin{abstract}
This paper presents an exploratory study on translators' decisions when encountering foodrelated translation difficulties in a parallel corpus of German original narrative texts and their translations into Spanish and Catalan. For this purpose, all food and drink related lexemes in the German original texts were extracted and classified in semantic groups. As a second step, the source and target text fragments of lexemes related to food-related cultural referents, metaphorical expressions or ways of eating and drinking were extracted and analysed in view of the techniques applied by the translators of both language combinations. The results obtained through the classification and quantification of the translation techniques in these three domains allow conclusions to be drawn regarding a) the existence of foreignizing or domesticating tendencies in the translation of food terms, b) the ways translators deal with action verbs that encompass multiple meaning aspects and c) the degree of metaphoricity and food-relatedness in the translation of metaphorical expressions.
\end{abstract}




\section{Eating and drinking seen through translation: A study of food- related translation difficulties and techniques in a parallel corpus of literary texts}

\section{Introduction ${ }^{1}$}

This paper presents the results of a corpus-based study focused on food-related translation difficulties in literary texts and how translators deal with them. The starting point for our study is twofold. On the one hand, eating and drinking, as essential human necessities, are inextricably cultural elements. On the other, some of the most visible differences among cultures are precisely those concerning eating habits, types of foods, the social roles of different meals and the rules related to them, and also the way some of these are encoded linguistically, in spite of the fact that there should be ample physiological common ground. Because of this combination of cultural and linguistic differences and the high frequency of food-related events in narrative fiction, literary translators are often faced with the necessity of making translation decisions when encountering descriptions of eating or drinking situations in a source text.

The aim is thus to present an exploratory study into tracing these decisions in a parallel corpus that includes German original narrative texts and their translations into Spanish and Catalan. As a great diversity of items relate to eating and drinking in literary texts, the scope of this paper has been narrowed to the translation of three specific aspects, namely food-related culturemes (in this case culture-specific food and drinks from Germany or Austria); actions carried out while eating and drinking (such as chewing or sipping); and metaphorical expressions in which food is the source domain (such as bitterness). The central question to address is how translators deal with these difficulties, i.e. what translation techniques they apply and whether there are discrepancies between the Spanish and Catalan target texts. As the three domains are rather diverse in nature, we will first very briefly present the background and rationale for each of the three parts of our study, leading us to specific research questions. 
As regards the translation of food-related culturemes, a wide variety of translation procedures has been described. Moreover, this is a field in which the dichotomy of domesticating vs. foreignizing approaches to literary translation (Venuti 1995) is especially visible. From the perspective of descriptive translation studies, our aim is therefore to find evidence for or against the idea that literary texts tend towards the foreignization of food terms (as suggested by Siran 2007). Through identifying the translation strategies or techniques applied to this phenomenon, it is intended to gain insight into the translation method(s) (cf. Hurtado Albir 2001:249) preferred by the translators of the works in the corpus.

For the translation of actions related to eating and drinking, the perspective is a more specific, source and target language-related one. German is known to encapsulate very specific meaning in action verbs, especially motion-related ones, both through the verb stem and through various prefixes. This may be related to the fact that different languages encode meaning dissimilarly and that systematic differences exist. As regards motion events, Talmy $(1985,1991)$ distinguishes satellite-framed languages and verb-framed languages. In satelliteframed languages (among which is German) information about the manner of motion is usually expressed through the verb stem (for example Max flitzte zu Peter hin - 'Max darted over to Peter'). In verb-framed languages like Spanish or Catalan, this is often omitted, but if considered relevant, it is usually expressed through gerunds, adverbs, or something similar (Max se dirigió como una flecha hacia Peter - 'Max went towards Peter like an arrow'). As expressed by Slobin (2000:110), “[T]he preferred pattern in such languages [verb-framed languages] is to use the main verb to encode simple motion (go) or directed motion (enter), expressing manner in an additional adjunct phrase, in those instances when manner is at issue." Accordingly, our questions are two: whether such highly specific verbs, in which there is complex information about the action or motion event, can also be found in relation to eating or drinking in our German corpus; and whether the translators found readily available lexical equivalents in the target languages or rather they had to look for more creative solutions.

Finally, the third part of the analysis will focus on the translation of food-related metaphorical expressions. For the purposes of this study, metaphor is understood in line with Conceptual Metaphor Theory as a way of expressing one conceptual domain in terms of another, mapping some elements of a source domain (in this case eating and drinking) onto a target domain (for instance, human behaviour or inanimate objects) in order to highlight certain characteristics. As with the previous aspects, our first aim is to analyse and classify the procedures applied in 
the translation of metaphorical expressions. Just as in the case of cultural referents (cf. section 3.1.1), translation scholars have long devoted considerable attention to the translation of metaphor (cf. Newmark 1980, Toury 1995, Snell-Hornby 1988, Zabalbeascoa 2001, 2004, among many others). Although the traditional concept of metaphor might not equate exactly to what is meant here by "metaphorical expression", many of the procedures mentioned in those studies are reflected in our own classification. Through the analysis, we aim to find out whether the translation solutions contribute to a similar degree of metaphoricity in the target text, and if so, whether food continues to play a role in the metaphor.

\section{Method}

\subsection{Corpus description}

The corpus used in this study is part of the multilingual COVALT corpus, still under construction, made up of the Catalan translations of narrative works originally written in English, French and German. It currently includes 70 text pairs (source plus target), which amount to about four million words and is being extended to Spanish translations (cf. Guzman 2013, Oster \& van Lawick 2013). The corpus has been built for the purpose of translation research, specifically the investigation of translated Catalan and Spanish. This is why the main criterion for achieving homogeneity lies in the choice of the target texts: they are contemporary translations of narrative fiction published between 1980 and the present in the autonomous community of Valencia in the case of Catalan, and in Spain in the case of Spanish. In order to reflect the reality of the type of narrative works that have been translated in these decades into the two languages, literature both for young people and adults was considered. The German subcorpus of COVALT contains 18 works. For this comparative study that includes two target languages, however, the corpus had to be narrowed down because only 13 of the German originals ${ }^{2}$ were available both in Spanish ${ }^{3}$ and in Catalan ${ }^{4}$. The original German corpus contains a total of 282,739 words and their Spanish and Catalan translations have similar word-counts: 297,922 and 311,047 respectively.

\subsection{Procedure}

As a first step, all food and drink related lexemes in the German original texts were extracted manually. In order to spot these lexemes, we proceeded through the lemmatized wordlist of the German corpus to classify them by semantic subtype, like the following: 
- Types of food $\rightarrow$ Rosenkohl ('Brussels sprouts'), Leberwurst ('liver sausage').

- Types of drink $\rightarrow$ Zitronenlimonade ('lemonade'), Tischwein ('table wine').

- Properties of food $\rightarrow$ süß ('sweet'), ranzig ('rancid').

- Types of meals $\rightarrow$ Abendbrot ('supper'), Mahlzeit ('meal').

- Parts or portions of foodstuff $\rightarrow$ Schluck ('gulp', 'sip'), Brösel ('crumb').

- Ways of preparing food $\rightarrow$ braten ('to fry', 'to roast'), umrühren ('to stir').

- Objects $\rightarrow$ Teller ('plate'), Nussknacker ('nutcracker').

- Places $\rightarrow$ Küche ('kitchen'), Speisekammer ('pantry').

- Persons $\rightarrow$ Zuckerbäcker ('confectioner'), Wirt ('innkeeper').

- Parts of the body $\rightarrow$ Zunge ('tongue'), Kehle ('throat').

- States of persons $\rightarrow$ hungrig ('hungry'), angeheitert ('tipsy').

- Sensations $\rightarrow$ ekelhaft ('nauseating'), genießen ('to relish').

- Actions, especially ways of eating and drinking $\rightarrow$ schmatzen ('to eat noisily'), schlucken ('to swallow'), löffeln ('to eat with a spoon').

- Food-based descriptive adjectives $\rightarrow$ eiförmig ('egg-shaped'), milchweiß ('milky white').

- Metaphorical expressions $\rightarrow$ sich verzehren ('to consume oneself'), stocksauer ('very angry', literally 'sour').

From this classification, three items were selected for analysis in this paper:

1. The treatment of culinary or food-related cultural referents or culturemes (cf. Rodríguez Abella 2008), i.e. those members of the categories "types of food" and "types of drink" that are culture-specific.

2. Ways of eating and drinking.

3. Metaphorical expressions that have food or drink as their source domain.

Once the lexemes had been chosen, the source and target text fragments were extracted for analysis. Very briefly, the technical procedure of corpus searches can be explained as follows. For the German-Spanish corpus, the interface IMS Open Corpus WorkBench (CWB) was used for indexing the previously aligned source and target texts. Then, with the help of CWB's Corpus Query Processor (CQP), all instances of our list of German expressions referring to the three aspects mentioned above were extracted together with their translations into Spanish. CQP creates a simple .txt document containing the query results, which can then be analysed 
and classified (cf. Christ et al. (1999), Evert \& OCWB (2005) and Molés-Cases (in press) for more information about CWB),

Due to technical difficulties with tagging the Catalan texts, for the German-Catalan corpus we resorted to Alfracovalt, bilingual concordancing software designed for the COVALT corpus by Josep Guzman (for more information about the software cf. Guzman \& Serrano (2006). Although this product cannot perform as complex queries as CQP does, it was sufficient for the purposes of this study.

The bilingual concordances extracted from both sub-corpora (German-Spanish and GermanCatalan) were then analysed with the intent to describe the different techniques employed by the translators of these texts into Spanish and Catalan, as well as to address the individual research questions for each of the above three aspects. As a certain degree of subjectivity is inevitable in classifying translation techniques as well as in adopting a specific list of techniques, this process was done in several steps. First, all the expressions were classified independently by both researchers. Discrepancies in the classifications were then discussed, leading to the establishment of specific criteria for problematic cases, which were then applied coherently to the whole data set. This procedure was applied for all three aspects: food-related culturemes, ways of eating and drinking, and metaphorical expressions.

\section{Results}

\subsection{Food-related culturemes}

\subsubsection{Classification}

The classification is based on the solutions found in our corpus and following a long tradition of typologies of translation strategies and techniques that range from general purpose taxonomies (Vinay \& Darbelnet 1985; Vázquez Ayora 1977; Newmark 1988; Delisle 1993; Chesterman 1997; Molina 2001; Molina \& Hurtado 2002) to classifications of techniques for specific translation problems like cultural referents (Newmark 1988; Florin 1993; Hervey, Higgins \& Haywood 1995; Katan 1999; Marco 2002, 2004) or proper nouns (Mayoral 1999/2000). Through this bottom-up and top-down process seven different techniques have been distinguished.

A. Intercultural adaptation 
Definition: The use of a target culture concept approximately equivalent to the source text concept (cf. Marco 2004:137).

Example: The German dish Gemüse-Eintopf ('vegetable stew or soup') is translated by using the name of a similar Spanish dish that is clearly a Spanish cultural referent consisting of mixed stir fried vegetables (menestra de verduras). ${ }^{5}$
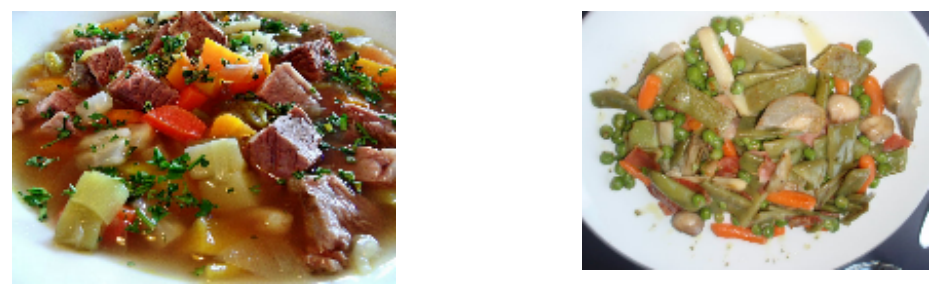

Figure 1: Gemüseeintopf ${ }^{6}$ vs. menestra de verduras ${ }^{7}$

B. Intracultural adaptation

Definition: A source text concept is substituted with another concept from the source culture (or a literal translation thereof) that is more familiar to the target text reader (cf. Marco 2004).

Example: Lebkuchen is a German Christmas pastry as seen in the first photograph, but in the source text, Lebkuchen is mostly related to Lebkuchenmann, a concept evoking an image closely associated with that of the Catalan translation equivalent pa de gingebre ('ginger bread'). This is not, however, a concept of the target culture, but is known through film and literature as part of British or American culture.
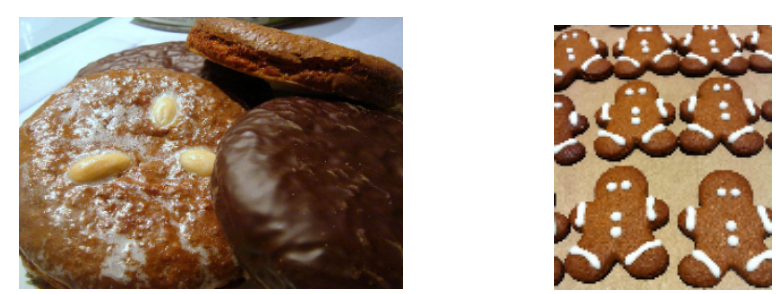

Figure 2: Lebkuchen $^{8}$ vs. pa de gingebre ${ }^{9}$

C. Neutralization

If a concept is neutralized, it ceases to be a cultural referent in the target text. There are two principal means of doing this: generalization and description. 


\section{C1. Generalization}

Definition: The use of a more general term (cf. Molina \& Hurtado 2002).

Example: The German expression Butterbrot ('buttered bread'), a very simple traditional evening or take-along meal, is rendered in Spanish as pan ('bread'). Apart from the prototypical Brot being quite unalike pan, the translation disregards all additional connotations (and the butter, of course) and lifts the concept to a more general level.
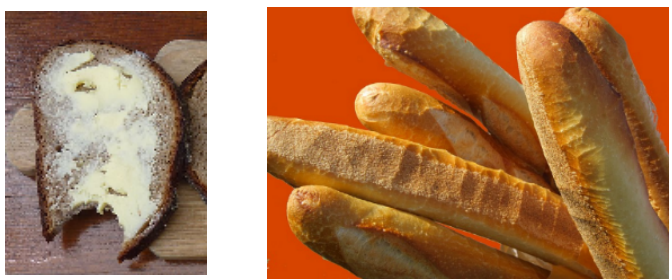

Figure 3: Butterbrot ${ }^{10}$ vs. pan $^{11}$

\section{C2. Description}

Definition: The use of a description of a concept's form and/or function (cf. Molina \& Hurtado 2002).

Example: The German Negerkuss, an extremely popular sweet consisting of sweet foam coated thinly with chocolate, is translated as bola de chocolate rellena de nata ('ball of chocolate filled with cream'). What is special about this example is that the description is not completely accurate. Nonetheless, it approximates adequately and is possibly more appealing to a child than a precise definition would. This shows that even in the case of the more source-culture oriented technique of description, the translator can intervene and draw the text closer to the target reader.

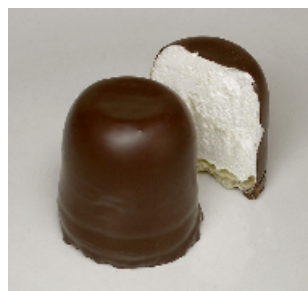

Figure 4: Negerkuss ${ }^{12}$

D. Omission 
Definition: The elimination of elements considered redundant or unimportant (cf. Marco 2004).

Example: In a rather long list of sweets for children, several are ignored in the translation, especially the more culture-specific, like Gummibärchen ('gummy bears'), which is rendered in the Catalan version as $i$ d'altres llepolies ('and other sweets').

E. Re-creation

Definition: The coining of a new expression in the target language as the translation of a source language concept.

Example: $\quad$ Spekulatius is another spicy Christmas biscuit with a characteristic form. The Spanish translation pasta de pastaflora has been classified as re-creation because the translation was published in mainland Spain, where this expression sounds poetic and appealing, but is very uncommon, pastaflora being a specialized bakery term that refers to a type of dough similar to shortcrust pastry. Pasta flora or pastafrola does exist in South America, especially in countries of the Southern Cone, where it designates a type of cake like the one in the picture.
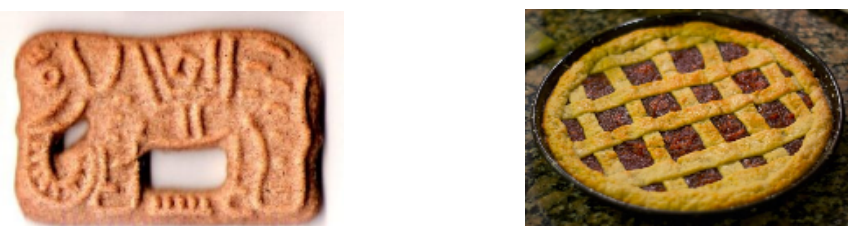

Figure 5: Spekulatius ${ }^{13}$ vs. pasta de pastaflora $^{14}$

However, this is the only case of re-creation of an existing cultural referent. In the corpus, this procedure is used mainly for invented concepts that belong to a fictitious world, like Neunkraft (literally translated into English as 'nine-force'), translated as sietebrios into Spanish ('seven forces'). Not simply literal, the number nine has been substituted by seven, for its more magical connotations, and a more poetic equivalent brio ('energy', 'spirit') has been chosen for the plainer German Kraft ('force').

E. Literal translation 
This last procedure, although possible as a general translation technique, was found in the corpus exclusively in the case of invented foodstuff belonging to a fictive world.

Definition: The use of word-for-word translation (or calque) of a complex source language expression (cf. Marco 2004).

Example: $\quad$ The German expression Erdbirnen ('earth pears'), a new creation paralleling the regional Austrian variant for potatoes Erdäpfel ('earth apples'), is translated word-for-word into Spanish: peras de tierra.

\section{F. Combination of techniques}

Lastly, we find that techniques are sometimes combined. This is the case of the Austrian Wurstsemmel ('roll with cold cuts'), translated as bocadillo de salchicha ('sausage sandwich'). This might sound like a description or literal translation, especially taking into account the polysemy of Wurst ('cold cuts' or 'bologna' vs. 'sausage'), but it actually describes a slightly different concept that also belongs to the source culture, the typical German sausage roll. This is why this translation has been classified as a combination of description and intracultural adaptation.
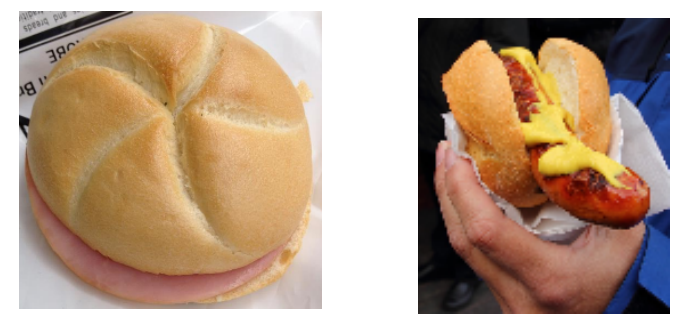

Figure 6: Wurstsemmel $^{15}$ vs. bocadillo de salchicha ${ }^{16}$

\subsubsection{Quantification}

Table 1 quantifies the spread of translation techniques for real-world food and drink cultural referents (i.e. excluding the invented ones). For invented foodstuff, the preferred technique for both languages is literal translation, used in eight out of nine instances, the exception being one case of re-creation mentioned earlier.

On the whole, the data show clearly that there is no marked variation among the Spanish and Catalan translations. Looking at individual translation solutions, however, it must be noted that in twelve out of 30 cases, translators have chosen different procedures for the same 
source language item. For example, Gummibärchen omitted in Catalan have been rendered through an intercultural adaptation in Spanish and translated as gominolas ('jelly beans').

\begin{tabular}{lccc} 
& Spanish translations & Catalan translations & Total \\
\hline Intercultural adaptation & 8 & 9 & $\mathbf{1 7}$ \\
\hline Intracultural adaptation & - & 2 & $\mathbf{2}$ \\
\hline Generalization & 8 & 7 & $\mathbf{1 5}$ \\
\hline Description & 10 & 8 & $\mathbf{1 8}$ \\
\hline Omission & 1 & 3 & $\mathbf{4}$ \\
\hline Total & $\mathbf{2 7}$ & $\mathbf{2 9}$ & $\mathbf{5 6}$ \\
\hline
\end{tabular}

Table 1. Quantification of results: Translation techniques for culinary culturemes

Marco's continuum of "culturicity" in translation techniques for cultural referents is the degree to which the translation solution is or is not a cultural referent in the target language as well (Marco 2004: 140). Taking this into account, a stronger tendency towards techniques that reduce the degree of culturicity of the translation solution can be observed, namely the neutralizing procedures of generalization (15 cases) and description (18 cases). On the other hand, from the point of view of the foreignization-domestication dichotomy, only the technique of intracultural adaptation and to some extent that of description might be considered foreignizing, together with other possible procedures not found in this corpus like the inclusion of loanwords or literal translation (only found for invented foodstuff). This means that in 65 percent of the cases analysed (36 out of 56) the translator endeavours to bring the text closer to the target reader by reducing the source culture specificity of food and drink related items.

\subsection{Ways of eating and drinking}

\subsubsection{Classification}

Let us now examine more closely the verbs used to express actions related to eating and drinking. Regarding our first question, namely whether the German corpus would yield such highly specific verbs in the domain of eating and drinking, 32 of such verbs were located, most of which express a complex action. ${ }^{17}$ In accordance with the satellite-framed character of German, twelve of them are prefixed verbs.

The question therefore arises as to what the translators did to convey the meaning. Did they find readily available lexical equivalents in the target languages, or did they have to find more creative solutions? In order to answer these questions, the solutions provided by translators 
into Catalan and Spanish were analysed and then classified according to the following techniques:

\section{A. Choosing a lexical equivalent}

This technique occurs when the translator uses a lexical equivalent in the target text that maintains all relevant meaning aspects. As regards the semantic content of the food-related action, we differentiate two cases as shown in Table 2, a simple action or an action combined with manner.

\begin{tabular}{|c|c|c|c|}
\hline $\begin{array}{l}\text { Semantic content } \\
\text { (German) }\end{array}$ & $\begin{array}{l}\text { Semantic content } \\
\text { (Spanish/Catalan) }\end{array}$ & Example (German) & $\begin{array}{l}\text { Spanish or Catalan } \\
\text { translation }\end{array}$ \\
\hline action & action & beißen ('to bite') & morder ('to bite') \\
\hline action/manner ${ }^{18}$ & action/manner & mampfen ('to munch') & zampar ('to munch') \\
\hline
\end{tabular}

Table 2. Translation techniques for food-related actions: Choosing a lexical equivalent

B. Paraphrasing the complex meaning of a source text element

When the food-related action is expressed in a condensed way in the German original, like in the verb löffeln ('to eat with a spoon'), the translator can decide to maintain all the meaning aspects by paraphrasing it in a more complex expression (cf. Table 3), for example by using a verb and introducing the instrument through a prepositional phrase (a cucharaditas - 'in little spoonfuls').

\begin{tabular}{llll}
$\begin{array}{l}\text { Semantic content } \\
\text { (German) }\end{array}$ & $\begin{array}{l}\text { Semantic content } \\
\text { (Spanish/Catalan) }\end{array}$ & Example (German) & $\begin{array}{l}\text { Spanish or Catalan } \\
\text { translation }\end{array}$ \\
\hline
\end{tabular}

action/instrument action + instrument ${ }^{19}$ löffeln ('to eat with a comer a cucharaditas spoon') ('in little spoonfuls')

Table 3. Translation techniques for food-related actions: Paraphrasing complex meaning

C. Reduction

On the other hand, there are several ways in which the complexity of the action can be reduced (cf. Table 4). This can be achieved either through a more general lexical equivalent or by removing part of the meaning aspects, mainly manner, but sometimes also instrument, attitude or result.

\begin{tabular}{llll}
$\begin{array}{l}\text { Semantic content } \\
\text { (German) }\end{array}$ & $\begin{array}{l}\text { Semantic content } \\
\text { (Spanish/Catalan) }\end{array}$ & Example (German) & $\begin{array}{l}\text { Spanish/Catalan } \\
\text { translation }\end{array}$ \\
\hline action & action (more & schlucken ('to & tomarse ('to take') \\
\hline
\end{tabular}




\begin{tabular}{|c|c|c|c|}
\hline & $\begin{array}{l}\text { general lexical } \\
\text { equivalent) }\end{array}$ & $\begin{array}{l}\text { swallow') } \\
\text { bekleckert ('to have } \\
\text { soiled your clothes with } \\
\text { food') }\end{array}$ & $\begin{array}{l}\text { cobert de ('covered } \\
\text { with') }\end{array}$ \\
\hline $\begin{array}{l}\text { action/manner }+ \\
\text { effect }\end{array}$ & action/effect & $\begin{array}{l}\text { vom Teller picken ('to } \\
\text { peck from the plate } \\
\text { (selectively)') }\end{array}$ & $\begin{array}{l}\text { retirar del plato ('to } \\
\text { clear the plate of } \\
\text { something.') }\end{array}$ \\
\hline action/manner & action & schlürfen ('to slurp') & $\begin{array}{l}\text { tomar unos sorbos ('to } \\
\text { take a few gulps') }\end{array}$ \\
\hline $\begin{array}{l}\text { action/instrument/ } \\
\text { attitude }\end{array}$ & action & $\begin{array}{l}\text { stochern ('to pick at } \\
\text { one's food with a } \\
\text { fork' } 20 \text { ) }\end{array}$ & remover ('to stir') \\
\hline action/result & action & zerkauen ('to chew up') & masticar ('to chew') \\
\hline
\end{tabular}

Conversely, as shown in Table 5, there are also instances in which the action is specified in a way not present in the source text, adding semantic components like manner.

\begin{tabular}{llll}
$\begin{array}{l}\text { Semantic content } \\
\text { (German) }\end{array}$ & $\begin{array}{l}\text { Semantic content } \\
\text { (Spanish/Catalan) }\end{array}$ & Example (German) & $\begin{array}{l}\text { Spanish/Catalan } \\
\text { translation }\end{array}$ \\
\hline action & action/manner & $\begin{array}{l}\text { verzehren ('to eat' } \\
\text { (neutral/formal) }\end{array}$ & devorar ('to devour') \\
\hline action + degree & $\begin{array}{l}\text { action/degree/ } \\
\text { manner }\end{array}$ & $\begin{array}{l}\text { aufgegessen ('eaten } \\
\text { up') }\end{array}$ & $\begin{array}{l}\text { zampado ('gulped } \\
\text { down') }\end{array}$ \\
\hline action + effect & action/effect + & $\begin{array}{l}\text { abbeißen ('to bite } \\
\text { maff') }\end{array}$ & $\begin{array}{l}\text { arrancar de un } \\
\text { mordisco ('tear off } \\
\text { with a bite') }\end{array}$ \\
\hline
\end{tabular}

Table 5. Translation techniques for food-related actions: Specification

E. Omission

Although the whole text fragment is translated, the action related to food or drink is excluded and instead made implicit. Table 6 shows examples of this technique.

\begin{tabular}{llll}
$\begin{array}{l}\text { Semantic content } \\
\text { (German) }\end{array}$ & $\begin{array}{l}\text { Semantic content } \\
\text { (Spanish/Catalan) }\end{array}$ & Example (German) & $\begin{array}{l}\text { Spanish/Catalan } \\
\text { translation }\end{array}$ \\
\hline $\begin{array}{l}\text { action + object + } \\
\text { purpose }\end{array}$ & object + action & $\begin{array}{l}\text { Heu zu fressen geben } \\
\text { ('to give some hay to } \\
\text { eat') }\end{array}$ & $\begin{array}{l}\text { dar heno ('to give } \\
\text { some hay') }\end{array}$ \\
\hline action & object & $\begin{array}{l}\text { viel zu fressen ('lots to } \\
\text { eat') }\end{array}$ & massapà ('marzipan') \\
\hline
\end{tabular}

Table 6. Translation techniques for food-related actions: Omissions

\subsubsection{Quantification}


The quantitative distribution of the translation techniques for food-related actions is shown in Table 7, which shows clearly that the results are very similar in Spanish and Catalan. Across both target corpora there is an overwhelming number of cases where an equivalent word or paraphrase was chosen for the translation. In some cases, part of the complex meaning is left out or occasionally more specific meaning aspects are introduced. In very few cases, the element is considered redundant and disregarded altogether.

\begin{tabular}{lccc} 
& Spanish translations & Catalan translations & Total \\
\hline Lexical equivalent & 53 & 54 & $\mathbf{1 0 7}$ \\
\hline Equivalent paraphrase & 7 & 7 & $\mathbf{1 4}$ \\
\hline Reduction & 9 & 8 & $\mathbf{1 7}$ \\
\hline Specification & 3 & - & $\mathbf{3}$ \\
\hline Omission & 2 & 3 & $\mathbf{5}$ \\
\hline Total & $\mathbf{7 4}$ & $\mathbf{7 2}$ & $\mathbf{1 4 6}$ \\
\hline
\end{tabular}

Table 7: Quantitative distribution of the translation techniques for food-related actions

The relatively high number of reductions (11.6 percent of all cases) could be explained through the claim made by Slobin (1996a, 1996b, 1997), McNeill (2000) and Özcalışkan \& Slobin $(2000,2003)$ that verb-framed languages (like Spanish and Catalan) tend to express manner of motion only when discursively relevant, i.e. indispensable for the characterization of the event, due to the higher cognitive load required to express manner in such languages (Slobin 2006). In most of the cases analysed here, however, translators have sought full equivalents, which contradicts the general tendency of verb-framed languages to express manner of motion to a lesser degree than satellite-framed languages do. This seems to indicate that translators try, first and foremost, to render meaning completely and accurately, and that this search for accuracy prevails over contrastive linguistic aspects like the one mentioned.

\subsection{Eating and drinking as a source domain for metaphorical expressions}

\subsubsection{Classification}

The third aspect chosen for the analysis is that of the translation of food-based metaphorical expressions. The following techniques were identified in the analysis of the bilingual concordances:

\section{A. Same metaphor}

Definition: Choosing a metaphor with the same or equivalent lexical base and the same or a very close meaning. 
Example: German verbittert is translated by means of Spanish amargado. Both are based on the conceptual domain of food (specifically taste) and achieve a very similar meaning close to the English 'filled with bitterness'.

B. Similar metaphor

Definition: Choosing a metaphor with the same or a similar lexical base and a similar meaning.

Example: The German expression abgeschmackt (literally, 'something that has lost its taste', i.e. 'tasteless or vulgar because of overuse') is translated by Spanish insípido ('without taste', i.e. 'boring'). In this case, the lexical base is practically the same, although the meaning is slightly different.

C. Different metaphor

Definition: Choosing a metaphor with a different lexical base (not food-related) but a similar meaning.

Example: In German, the metaphorical expression stocksauer ('completely sour') is used to convey that someone is very annoyed. This has been translated as humor de perros ('dog's mood'), borrowing an image from a completely different domain, but with a similar meaning ('in a very bad mood').

D. Calque

Definition: A literal translation of the metaphorical expression, especially when the target language expression does not seem idiomatic.

Example: In the German expression würgender Hunger, the adjective accompanying 'hunger' could be interpreted either as 'retching', i.e. 'hunger that makes you retch', or as 'squeezing your throat', the former probably being the more logical interpretation. However, the Catalan solution fam asfixiant ('suffocating hunger') chooses the latter one, producing a slightly puzzling metaphorical expression in the target text, with hunger depicted as affecting the respiratory rather than the digestive system. 
E. Non-metaphorical equivalent

Definition: Choosing a lexical equivalent that is not figurative.

Example: The expression unappetitlich ('unappetizing') loses its relation to the domain of food in the Spanish translation desagradable ('unpleasant'), which only retains the meaning, but not the underlying metaphorical mapping.

F. Omission

Definition: Eliminating the metaphorical expression.

Example: In the Catalan translation of German beißender Rauch ('biting (i.e. acrid) smoke'), the qualifying adjective is omitted: fum ('smoke').

\subsubsection{Quantification}

Our aim in this section is to find out whether translation solutions contribute to a similar degree of metaphoricity in the target text, and if so, whether food continues to play a part. The quantitative distribution of the translation techniques (Table 8) is revealing. It becomes apparent that a large proportion of the metaphorical expressions lose their relation to the domain of food and drink in the translated texts. This is the case in almost 70 percent of instances (techniques $\mathrm{C}, \mathrm{E}$ and F). Additionally, half of the translations do not include a metaphor at all (techniques $\mathrm{E}$ and F). Only in about 31 percent is a similar food-related metaphor used (A and B). In Table 8, the vertical arrow indicates the position of the translation techniques regarding the combined aspects of metaphoricity and food-relatedness. It is also worth noting that most of the metaphorical expressions found in the German corpus are rather conventionalized and even lexicalized (for example verbittert or abgeschmackt), which reduces the importance of the source domain 'food' for the comprehension process. This is probably the main reason for the prevalence of non-metaphorical translation solutions. In the corpus there are only three expressions in which the source domain seems more present and directly relevant for understanding and imagining the concept being described: würgender Hunger, Bulette ('meatball', used as a nickname for a boy) and, in spite of its lexicalisation, beißender Rauch. 


\begin{tabular}{|c|c|c|c|c|c|c|}
\hline & $\begin{array}{l}\text { Spanish } \\
\text { translations }\end{array}$ & $\begin{array}{l}\text { Catalan } \\
\text { translations }\end{array}$ & Total & \multirow{8}{*}{\multicolumn{2}{|c|}{ 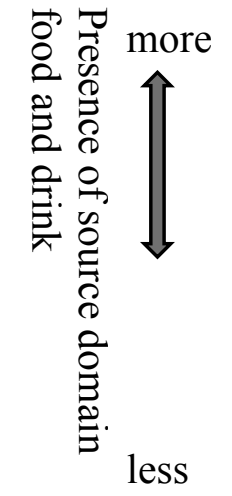 }} & \multirow{8}{*}{$\begin{array}{l}3 \\
0 \\
0 \\
0 \\
0 \\
0 \\
0 \\
0\end{array}$} \\
\hline A. Same metaphor & 3 & 3 & 6 & & & \\
\hline B. Similar metaphor & 2 & 4 & 6 & & & \\
\hline C. Different metaphor & 4 & 4 & 8 & & & \\
\hline D. Calque & - & 1 & 1 & & & \\
\hline $\begin{array}{l}\text { E. Non-metaphorical } \\
\text { equivalent }\end{array}$ & 12 & 8 & 20 & & & \\
\hline F. Omission & - & 1 & 1 & & & \\
\hline Total & 21 & 21 & 42 & & & \\
\hline
\end{tabular}

Table 8: Quantitative distribution of translation techniques regarding metaphorical expressions

\section{Discussion}

Our analysis was intended to be a pilot study in order to identify a) a viable procedure for analysing the translation of items related to the domain of eating and drinking, b) sub-domains that are interesting from a translation point of view, and c) strategies or techniques employed by translators.

The procedure described here harnesses advanced software developed for corpus analysis. Two tools were used for corpus queries, Corpus Query Processor and Alfracovalt, and both programs, regardless of their specific features, proved to be fast and successful in performing searches. Another advantage for both is the output of query results being .txt documents, which facilitates the storage and further processing of the data. One of the most timeconsuming steps in the procedure is the manual extraction of food-related terms from the lemmatized wordlist of the source text corpus. This is manageable with a relatively small corpus like ours (around 300,000 words in each subcorpus). However, when considering applying the procedure to larger corpora in order to arrive at more representative findings, this manual phase might place constraints on corpus size, even if enlarging the corpus does not lead to a wordlist increase of the same factor (due to the decreasing type-token ratio in bigger corpora). On the other hand, limiting the study to items that appear with a minimum frequency of two, three or even more tokens - which would shorten the wordlist considerably - does not seem to be a useful solution: In our sample the infrequent items often proved to be especially interesting from a translation point of view.

As to the identification of sub-domains relevant for translation, food-related cultural referents and metaphorical expressions proved to be the most interesting among the three aspects. On 
the other hand, it might be useful to study other sub-domains that could not be covered in this paper like food-based descriptive adjectives (for example dottergelb 'yellow like yoke', brühwarm 'warm like broth'), descriptions of persons (Kirschennase 'cherry nose', Apfelbacken 'apple cheeks') and other creative and even curious expressions (Eiswürfelblick 'ice cube look', Gurkenfächer 'cucumber fan, i.e. cucumber slices arranged like a fan').

Regarding the techniques employed by the translators, the following conclusions were reached: With respect to the translation of foodstuff, techniques that reduce the degree of culturicity are employed more often than those that maintain it; there also seems to be a tendency towards a domesticating approach in our corpus, which is contrary to Siran's (2007) suggestion that foreignizing seems more appropriate for the translation of literary texts. It should be taken into account, however, that our corpus is partly composed of literature for younger people and that many of the food-related terms have come from these texts. In this sense, our findings are consistent with those of House (2004), who states that: "Cultural conversions take place in the translation of children's literature whenever source cultural norms are deemed 'undesirable': names, foods, drinks, clothes, etc. are often converted haphazardly or systematically." (House, 2004: 686). It would therefore be interesting to complement this study with one that contrasts results from different genres.

The translation of actions pertaining to ways of eating and drinking, on the other hand, does not seem to be a particularly problematic area. In most cases, the translators used a lexical or paraphrastic equivalent that covers all relevant meaning aspects. It is notable, however, that in almost twelve percent of cases one or more meaning aspects were omitted, resulting in a generalization of the action.

Finally, as regards the translation of food-related metaphorical expressions, it has become clear that in this domain the translations are much less metaphoric (only half of the expressions maintain their metaphoricity in translation) and that the source domain "food" is less present than in the source texts.

\section{Concluding remarks}

From a more global perspective, data obtained from the Spanish and Catalan translations proved to be very similar on the whole, although for individual translation problems the techniques chosen by the translators are often different. We conclude that the translation of 
food and drink is such that the translator has considerable potential to intervene and adopt techniques that make the target text either more domesticated or foreignized, to bring it closer to either the target or source culture, to make it more or less explicit in conveying specific meaning, or to make it more or less metaphoric. However - at least on the grounds of this small corpus - there seems to be no reason to hypothesize a difference in translator behaviour between these two language combinations.

Similarly, the study could be extended to other languages, such as English and French, both being part of the COVALT corpus too. This would shed light on whether the source language influences the translation procedures, especially when comparing translations from another Germanic language (English into Spanish/Catalan) and those between different Romance languages (French into Spanish/Catalan). For example, typological differences might be relevant for the ways of eating and drinking, i.e. the encoding of manner. In this respect, it might also be interesting to run a similar study in the inverse translation combinations (especially from Spanish or Catalan into the verb-framed languages English and German). This would make it possible to check whether generalizations in one direction are counterbalanced or not by specifications in the inverse linguistic combination (cf. the asymmetry hypothesis proposed by Klaudy \& Károly 2005; Klaudy 2009). Furthermore, regarding the translation of culinary cultural referents, a comparison of the frequency of techniques used in translations from Spanish and Catalan into English would be interesting. It might confirm whether similar tendencies can be observed, or if, as suggested by Grammenidis (2014), translation techniques might be influenced by the target language being more peripheral or more central, resulting in a stronger tendency towards domestication in translations into languages of more hegemonic cultures.

\section{References}

Chesterman, A. 1997. Memes of translation. Amsterdam/Philadelphia: John Benjamins.

Christ, O. et al. 1999. The IMS Corpus Workbench. Corpus Query Processor. User's Manual. Stuttgart: University of Stuttgart. Available at http://corpora.dslo.unibo.it/TCORIS/cqpman.pdf. [12/09/2014].

Delisle, J. 1993. La traduction raisonnée. Manuel d'initiation à la traduction professionnelle de l'anglais vers le français. Ottawa: Les Presses de l'Université d'Ottawa.

Evert, S. \& OCWB. 2005. The CQP Query Language Tutorial. Available at: http://cwb.sourceforge.net/files/CQP_Tutorial.pdf. [5/07/2014]. 
Florin, S. 1993. Realia in translation. In Zlateva, P. ed. Translation as social action. Russian and Bulgarian Perspectives. London: Routledge. 122-128.

Grammenidis, S. 2014. Practical Trends and Theoretical Issues in Mediating Culinary Culture: Peripheral vs. Central Cultures. Paper presented at First International Conference on Food and Culture in Translation (22-24 May, 2014), Bertinoro, Forlì, Italy.

Guzman, J. \& Serrano, À. 2006. Alineamiento de frases y traducción: AlfraCOVALT y el procesamiento de corpus. Sendebar Vol. 17. 169-186.

Guzman, J. R. 2013. El corpus COVALT i l'eina d'alineament de frases Alfra-COVALT. In: Bracho Lapiedra, L. (ed) El corpus COVALT: un observatori de fraseologia traduïda. Aachen: Shaker. 49-60.

Hervey, S. et al. 1995. Thinking Spanish Translation. A Course in Translation Method: Spanish to English. London: Routledge.

House, J. 2004. Linguistic Aspects of the Translation of Children's Books. In: Kittel, H., J. House \& B. Schultze (eds) Übersetzung - Translation - Traduction. An International Handbook. Berlin: Mouton de Gruyter. 683-697.

Hurtado Albir, A. 2001. Traducción y traductología. Introducción a la traductología. Madrid: Cátedra.

Katan, D. 1999. Translating Cultures. An Introduction for Translators, Interpreters and Mediators. Manchester: St. Jerome.

Klaudy, K. \& Károly, K. 2005. Implicitation in translation: empirical evidence for operational asymmetry in translation. Across languages and cultures. Vol. 6. No. 1. 12-28.

Klaudy, K. 2009. The asymmetry hypothesis in translation research. In: Dimitru, M. et al. (eds) Translators and their readers. In Homage to Eugene A. Nida. Brussels: Editions du Hazard. 283-303.

Marco, J. 2002. El fil d'Ariadna. Anàlisi estilística i traducció literària. Vic: Eumo.

Marco, J. 2004. Les tècniques de traducció (dels referents culturals): retorn per a quedar-nos hi. Quaderns - Universitat Autònoma de Barcelona. Departament de Traducció $i$ d'Interpretació 11. 129-149.

Mayoral, R. 1999/2000. La traducción de referencias culturales. Sendebar Vol. 10 No. 11. $67-88$.

McNeill, D. 2000. Analogic/Analytic representations and cross-linguistic differences in thinking for speaking. Cognitive Linguistics Vol. 11. No. 1/2. 43-60. 
Molés-Cases, T. in press. “Compilación y análisis de un corpus paralelo para la investigación en traducción. Proyecto con Déjà Vu, TreeTagger e IMS Open Corpus Workbench". Revista de Lingüística Teórica y Aplicada (RLA).

Molina, L. 2001. Análisis descriptivo de la traducción de los culturemas árabe-español. Master's thesis. Supervision: Amparo Hurtado Albir. Universitat Autònoma de Barcelona.

Molina, L. \& Hurtado, A. 2002. Translation Techniques Revisited: A Dynamic and Functionalist Approach. Meta Vol. 47. No. 4. 498-512.

Newmark, P. 1980. The translation of metaphor. Babel Vol. 26. 93-100.

Newmark, P. 1988. A textbook of translation. New York: Prentice-Hall International.

Oster, U. \& van Lawick, H. 2013. Anàlisi dels somatismes del subcorpus alemany-català. In: Bracho Lapiedra, L. (ed) El corpus COVALT: un observatori de fraseologia traduïda. Aachen: Shaker. 267-294.

Özçalışkan, S. \& Slobin, D. I. 2000. 'Climb up' vs. 'ascend climbing': Lexicalization choices in expressing motion events with manner and path components. In: Howell, S. C. et al. (eds) Proceedings of the 24th Boston University Conference on Language Development. Somerville, MA: Cascadilla Press. 558-570.

Özçalışkan, S. \& D. I. Slobin. 2003. Codability Effects on the Expression of Manner of Motion in Turkish and English. In: Ozsoy, A. S. et al. (eds) Studies in Turkish linguistics. Estambul: Boğaziçi University Press. 259-270.

Rodríguez Abella, R. M. 2008. El hombre de mi vida: análisis de la traducción de los culturemas del ámbito gastronómico. In: Navarro, C. et al. (eds) La comunicación especializada. Frankfurt am Main: Peter Lang. 319-155.

Siran, H. 2007. La Extranjerización y la Domesticación de la Traducción Gastronómica según la tipología textual. Master's thesis. Supervision: Sara Rovira-Esteva. Universitat Autònoma de Barcelona.

Slobin, D. I. 1996a. From 'thought and language' to 'thinking for speaking'. In: Levinson, S. C. \& Gumperz, J. J. (eds) Rethinking linguistic relativity. Cambridge: Cambridge University Press. 70-96.

Slobin, D. I. 1996b. Two ways to travel: Verbs of motion in English and Spanish. In: Shibatani, M. \& Thompson, S.A. (eds) Grammatical Constructions: their form and meaning. Oxford: Clarendo Press. 195-220. 
Slobin, D. I. 1997. Mind, code and text. In: Bybee, Joan L. et al. (eds) Essays on language function and language type. Dedicated to T. Givón. Amsterdam/Philadelphia: John Benjamins. 438-467.

Slobin, D. I. 2000. Verbalized events: A dynamic approach to linguistic relativity and determinism. In: Niemeier, S. \& Dirven, R. (eds) Evidence for linguistic relativity. Berlin: Mouton de Gruyter. 107-138.

Slobin, D. I. 2006. What makes manner of motion salient? In: Hickmann, M. \& Robert, S. (eds) Space in Languages: Linguistic Systems and Cognitive Categories. Amsterdam/Philadelphia: John Benjamins. 59-82.

Snell-Hornby, M. 1988: Translation Studies: An Integrated Approach. Amsterdam/Philadelphia: John Benjamins.

Talmy, L. 1985. Lexicalization patterns: Semantic structures in lexical forms. In: Shopen, T. (ed) Language typology and syntactic description. Cambridge: Cambridge University Press. 57-149.

Talmy, L. 1991. Path to realization: A typology of event conflation. Proceedings of the Seventeenth Annual Meeting of Berkeley Linguistics Society (15-18 Februar, 1991). Berkeley. 480-519.

Toury, G. 1995. Descriptive Translation Studies and Beyond. Amsterdam/Philadelphia: John Benjamins.

Vázquez Ayora, G. 1977. Introducción a la traductología: curso básico de traducción. Washington: Georgetown University Press.

Venuti, L. 1995. The Translator's Invisibility. London: Routledge.

Vinay, J-P. \& Darbelnet, J. 1958. Stylistique comparée du français et de l'anglais. Méthode de traduction. Paris: Didier.

Zabalbeascoa, P. 2001. Un marco para el análisis de la traducción de la metáfora. In: Barr, A. \& Martín Ruano, M.R. (eds) Últimas corrientes en los estudios de traducción y sus aplicaciones. Salamanca: Universidad de Salamanca. 858-868.

Zabalbeascoa, P. 2004. Translating non-segmental features of textual communication: The case of metaphor within a binary-branch analysis. In: Hansen, G. et al. (eds) Claims, Changes and Challenges in Translation. Selected contributions from the EST Congress (Copenhagen 2001). Amsterdam/Philadelphia: John Benjamins. 99-11.

\footnotetext{
${ }^{1}$ This study has been supported by research projects FFI2012-35239, funded by the Spanish Ministry for the Economy and Competition, and P1-1B2013-44, funded by Universitat Jaume I.

${ }_{2}^{2}$ The German works of narrative fiction used in this study are the following: Peter Schlemihls wundersame Geschichte (1938, Adelbert von Chamisso), Die Verwandlung (2001, Franz Kafka), Brief an den Vater (2001,
} 
Franz Kafka), Die Flucht ohne Ende (1994, Joseph Roth), Geschichten von Herrn Keuner (1971, Bertolt Brecht), Vorstadtkrokodile (1976, Max von der Grün), Der Neue Pinocchio (1988, Christine Nöstlinger), Die Unterirdischen (1988, Angela Sommer-Bodenburg), Die Geschichte von der Schüssel und vom Löffel (1990, Michael Ende), Wenn du dich gruseln willst (1990, Angela Sommer-Bodenburg), Spürnase Jakob-Nachbarkind (1992, Christine Nöstlinger), Als der Weihnachtsmann vom Himmel fiel (1994, Cornelia Funke), Die Zauberschule (1995, Michael Ende).

${ }^{3}$ The Spanish translations used in this study are the following: La maravillosa historia de Peter Schlemihl (1994, translated by Hernán Valdés), La metamorfosis (2004, César Aira), Carta al padre (1983, Feliu Formosa), Fuga sin fin (2003, Juan Luis Verbal), Historias del señor Keuner (1996, Rosana Terzi), Los cocodrilos del barrio (2008, Vicent Manuel Sanz Esbrí), El nuevo Pinocho (1988, Manuel Ramírez Giménez), El mundo subterráneo (1989, Herminia Dauer), La sopera y el cazo (1996, Rosana Terzi), Historias de miedo (1991, Azucena Viloria Serrano), Olfato de detective (1995, Rosa Pilar Blanco), Cuando Papá Noel cayó del cielo (2006, Rosa Pilar Blanco), La escuela de magia (1995, Miguel Azaloa).

${ }^{4}$ The Catalan translations used in this study are the following: La meravellosa història de Peter Schlemihl (1988, Gustau Llobet), La metamorfosi (2009, Jordi Llovel), Carta al pare (1995, Heike van Lawick), La fugida sense fi (1995, Heike van Lawick), Històries del senyor Keuner (1995, Anacleto Ferrer \& Marc Granell), La colla dels cocodrils (2000, Jesús Cortés), El nou Pinotxo (1988, Heike van Lawick), El món subterrani (2008, Josep Franco), La sopera i el cullerot (2004, Josep Franco), Històries de por (1996, Francesc Martí), Olfacte de detectiu (2006, Neus Andreu), Quan el Pare Noel va caure del cel (2006, Carles Miró), Els millors contes ('L'escola de màgia') (2004, Josep Franco).

${ }_{5}$ As images are able to convey differences more easily than words, the dish descriptions are accompanied by photographs. All of them are free for non-commercial use.

${ }^{6}$ Author: Josef Türk Jun. http://de.wikipedia.org/wiki/Pichelsteiner\#mediaviewer/File:Pichelsteiner_Eintopf.jpg

${ }^{7}$ Author: Mover el Bigote: http://commons.wikimedia.org/wiki/File:Menestra_-moverelbigote.jpg

${ }^{8}$ Author: Leon Brocard:

http://de.wikipedia.org/wiki/Lebkuchen\#mediaviewer/File:N\%C3\%BCrnberger_Lebkuchen.jpg

${ }^{9}$ Found at: http://pixabay.com/es/pan-de-jengibre-hombre-las-cookies-226628/

${ }^{10}$ Author: Xocolatl: http://commons.wikimedia.org/wiki/File:Butterbrot_angebissen.jpg

${ }^{11}$ Found at: http://pixabay.com/es/baguette-pan-alimentos-177858/

${ }^{12}$ Author: Rainer Z.: http://commons.wikimedia.org/wiki/File:Schaumkuss-1.jpg

${ }^{13}$ Found at: http://commons.wikimedia.org/wiki/File:Spekulatius_four_pieces_of.jpg

${ }^{14}$ Author: Pastelero: http://commons.wikimedia.org/wiki/File:Pastafrola.jpg

${ }^{15}$ Author: Skyend:

http://commons.wikimedia.org/wiki/File:\%E3\%83\%B4\%E3\%83\%AB\%E3\%82\%B9\%E3\%83\%88\%E3\%82\%B C\%E3\%83\%B3\%E3\%83\%A1\%E3\%83\%AB.jpg

${ }_{17}^{16}$ Found at: http://pixabay.com/es/salchichas-salchicha-comida-r\%C3\%A1pida-235349/

17 abbeißen 'to bite off', aufessen 'to eat up', auffressen 'to devour', beißen 'to bite', bekleckert 'stained with food', fressen 'to eat (said of an animal)', füttern 'to feed', gurgeln 'to gargle', herumkauen 'to chew on something', kauen 'to chew', zerkauen 'to scrunch', knabbern 'to nibble', lecken 'to lick', löffeln 'to spoon', mampfen 'to munch', herumnagen 'to gnaw on something', benagen 'to gnaw on something', nagen 'to gnaw', picken 'to peck', rülpsen 'to belch', saugen 'to suck', Schluck nehmen 'to take a gulp', Schluck trinken 'to take a sip', schlucken 'to swallow', schlürfen 'to slurp', schmatzend 'eating noisily', stochern 'to pick', verkosten 'to taste', verputzen 'to scoff', verzehren 'to consume', sich verschlucken 'to choke on something', wegfuttern 'eat somebody else's food'.

${ }^{18}$ The slash between the two elements signifies that they are both present in the main verb.

${ }^{19}$ The plus sign between the two elements indicates that part of the meaning aspects is expressed through satellites.

${ }^{20}$ In the German expression im Essen stochern, not only has the action to be done with a fork or something similar, it also expresses an attitude, for example a reluctance to eat. 